\title{
Relationship between Orthodox Finance and Dividend Policy: A Literature Review
}

\section{Fakhrul Hasan*}

De Montfort University, United Kingdom

\begin{abstract}
This paper concentrates on the relationship between orthodox (corporate) finance and dividend policy. More specifically, the paper examines the relationship between different dividend policy theories and dividend policy. This paper also investigates the association between different corporate finance elements and dividend policy. The primary purpose of this paper is to put some light on the dividend literature, which means how dividend literature developed over the year. However still, the dividend policy is a puzzle for researchers. From the previous literature survey, we can see that after so much constrictive research, researchers still did not reach any conclusion. This paper provides details about previous literature reviews in the area of dividend policy.
\end{abstract}

Keywords: Dividend policy, dividend theories, financial elements

JEL Classification: G28, G32, G35, G53

Paper Type: Conceptual Paper

*Corresponding author: E-mail: fakhrulhasan87@gmail.com 


\section{INTRODUCTION}

Corporate Dividend policy is one of the essential components of firm policies. For companies' dividends act as an important conveyor of information; however, it is not clear why companies pay dividends or analogously why stockholders are interested in receiving dividends, given that it is well known that dividends are often taxed heavily, especially in the UK where the dividend tax is higher than the capital gain tax (Bozos, Nikolopoulos and Ramgandhi, 2011). This paper explained details about the relationship between orthodox finance and dividend policy. More specifically, this paper explained the relationship between dividend policy and dividend policy theories and between dividend policy and orthodox or corporate finance elements. This will help the reader understand how dividend policy theories and corporate finance key factors influence any given company's dividend announcements or dividend policy.

In his path-breaking work on dividends, Lintner's (1956) said that paying regular cash dividends to shareholders is a chronological tradition in developed capital markets. Lintner's (1956) argument was that company managers should understand that shareholders are entitled to get the firm's profits in the form of dividends. Numerous issues are considered when paying dividends, permanent earnings or earnings being one of them. Firms that pay dividends consider the relationship between the decision to pay dividends and earnings; studies have found that dividends vary according to profitability, growth, firm size, total equity, cash balance, and dividend history, a relation that also holds for dividend initiations and omissions.

Dividend changes are positively associated with stock returns in the days surrounding the dividend change announcement (Aharony and Swary, 1980); Asquith and Mullins, 1983; Kalay and Loewenstein, 1985 and Petit, 1972). Nissim and Ziv (2001) argue a relationship between dividend changes and future permanent earning changes. Dividend increases are positively related to unexpected earnings, but, on the other hand, dividend decreases are not significantly related to earning changes. According to Lintner (1956), dividend changes are more related to changes in permanent earnings. In contrast, Watts (1973) and Gonedes (1978) showed no relationship between current dividends and future earnings.

The theoretical models developed by Bhattacharya (1979) and Miller and Rock (1985) suggest that dividend policy changes convey news regarding future cash flows. They developed these theoretical models by using a critical economic notion of asymmetric information between managers and investors. The general implications of the dividendsignalling hypothesis are (1) a positive relationship between dividend changes and the price reaction to dividend changes; (2) a positive relationship between dividend changes and future earnings changes. This dividend hypothesis is one of the critical issues of corporate finance; therefore, surveys and discussions on this issue by incorporating several new viewpoints are valuable for the discipline. This dividend hypothesis is valuable, and new perspectives are needed because the puzzle has not been resolved yet.

This paper is organised as follows: Section 2 presents the relationship between dividend policy and dividend policy theories. In section 3, we examine the relationship between corporate finance elements and dividend policy. Section 4 presents the research implication and conclusion. 


\section{THE RELATIONSHIP BETWEEN DIVIDEND POLICY AND DIVIDEND POLICY THEORIES}

\subsection{Miller and Modigliani Dividend theory}

According to Miller and Modigliani (1961), in a perfect capital market, dividend payout policy is irrelevant to firm value because "(1) only investments, which generate future earnings and cash flows, affect firm value, and (2) investments are independent of dividends". Later Fama and Miller (1972) highlight an important caveat of this dividend irrelevance theorem, which is "Dividend policy should not affect investment decisions". In imperfect markets, dividend policy may influence investment decisions. When managers have more information about the firm's assets value and investment projects than outside investors, other problems can constrain the firm's access to external funds (Jensen and Meckling, 1976; Myers and Majluf, 1984). Recent research finds evidence consistent with dividends having a constraining or negative effect on investments (Ramalingegowda, Chun-San and Yong, 2013).

Investors' information set about future earnings changes when dividends change, and the earnings information itself is an essential part of the firm's underlying operations and hence should affect firm value, resulting in a potential "hopeless confounding of the real and purely informational effects" of dividends (Miller and Modigliani, 1966). Penman (1983) finds that dividend changes carry modest information after controlling for management forecasts of earnings. Kane et al. (1984) conclude that dividend changes transmit information incremental to earnings information announced in chorus. Lang and Litzenberger (1989) find that the price reaction to dividend changes is more significant for firms with lower expected profitability of future investments. They argue that this result supports the free cash flow hypothesis but is inconsistent with the dividend-signalling hypothesis.

Miller and Modigliani (1961) suggest that investors invest in a firm according to its dividend policy. Changes in the payout policy led to a change in the ownership structure. However, this payout change does not affect the firm's value because a priori no class of investors (called here clientele) is better than another. Shefrin and Thaler (1988) suggest that investors (or clientele) want different dividend yields due to taxation. Firms with low dividend yields are attractive for investors whose taxation is the highest; on the other hand, investors with a low level of taxation are interested in firms with high dividend yields.

According to Miller and Modigliani (1961) and Shefrin and Statman (1984), whether an investor is an individual or a pension fund, the optimal level of dividend yield can be different. Elton and Gruber (1970) measure the clientele effect by studying how the values of shares behave over the ex-dividend period. They use short term and long term taxation rates as equal, an equivalent taxation level for all investors and a homogeneous ownership structure. Elton and Gruber (1970) manage to find out the conditions in which an investor is indifferent when it comes to selling or buying a stock before or after the ex-dividend date.

In summary, investment decisions can be affected because of the dividend policy. Changes in dividend policy change investors' information set about future earnings. Dividend changes carry modest information after controlling for management earnings forecasts and transmit information incremental to earnings information announced in 
chorus. Investors decide to invest in a firm according to its dividend policy. A change in the payout policy leads to a change in the ownership structure.

\subsection{Life-Cycle Theory and Dividend Policy}

The life-cycle theory has been advanced by Fama and French (2001), Gullon et al. (2002) and DeAngelo et al. (2006). Life-cycle theory suggests that the trade-off between the advantages and disadvantages of earnings retention varies over the firm's life. In the early stage of profitability, all firms have a great investment opportunity. At the same time, they have less opportunity to internally generate cash when internal financing is cheaper than external financing. The prime decision is to maintain cash to fund growth. While these benefits of retention are widely accepted and empirically crucial in the literature, the motivations for later stage distributions are less so, probably because factors such as the agency costs of free cash flow are less easily measured than security issuance costs, tax penalties on pay-outs, and the stock-price impact of equity offerings.

The growing firms, which have abundant investment opportunities, should not return cash to shareholders in preparation for necessary investment for their future growth. Instead, they should prioritize retained earnings (RE). On the other hand, mature firms should return excess funds to shareholders to ease free cash flow problems (Jensen 1986). This idea is well known as the dividend life-cycle theory (Fama and French 2001; Grullon et al. 2002; Julio and Ikenberry 2004; DeAngelo and DeAngelo 2006; DeAngelo et al. 2006). In the US, there is evidence consistent with the theory. For example, DeAngelo et al. (2006) position a $R E$ ratio ( $=R E /$ book-value of equity) as a scale to express the stages of firm growth and presents evidence that firms with high RE (mature firms) pay dividends (Ishikawa, 2011).

Mature firms are more profitable and can internally generate cash over their investment requirements. The optimal policy will then be to retain sufficient earnings to invest in positive net present value projects and distribute excess cash to shareholders. When a firm pays dividends, it means that firm is reaching sustainable profitability. However, the amount of free cash flows depends on the firm's capital requirements to finance its growth. Generally, growing firms with abundant investment opportunities tend to have low free cash flows and, in turn, pay lower dividends. On the other hand, mature firms with inadequate profitable projects intend to have high free cash flows and make high dividend payments. Therefore, the firm's dividend policy appears to be affected by its life cycle. This is known as the life-cycle theory dividends (e.g., DeAngelo et al., 2006; Fama and French, 2001; Grullon et al., 2002).

Grullon, Michaely, Swaminathan (2002) find that dividend-increasing firms do not increase their capital expenditures in the years after dividend increases. Around dividend increase announcements, the systematic risk of dividend-increasing firms significantly declines. For that reason, those firms' cost of capital also declines significantly. Grullen et al. (2002) indicate that this decline in systematic risk is a significant determinant of the positive stock price reaction to dividend increases. Kane et al. (1984) documented that announcements of earnings and dividends are evaluated in conjunction with each other. According to Ishikawa (2011), dividend increases at an increase in earnings are more appreciated than at the time of a decrease in earnings. Ishikawa (2011) called this "corroboration effect." However, Ishikawa (2011) suggests that "factors that additionally cause an increase in stock prices in corroboration of the announcement of dividend increases do not only include a direct performance factor such as an increase in earnings". 
There is a positive (negative) correlation between dividends increases (decreases) and stock prices associated with the firm's growing stages. Ishikawa (2011) use PBR (Price to book-value ratio) as "growth". He found that the coefficient of a mature firm's dividend decreases is significantly negative. In contrast, the coefficient of a growing firm's dividend decreases is significantly positive. These results are consistent with the prediction by the dividend life-cycle theory. Free cash flow issues could further worsen if the market discounts a mature firm's dividend decreases. At the same time, the market also discounts a growing firm's dividend decreases but less than the usual decreases since they are preparations for future investment.

On the other hand, dividend increases are opposite to that predicted by the life-cycle theory. Ishikawa (2011) find that the coefficient of a mature firm's dividend increases is significantly negative. In contrast, the coefficient of a growing firm's dividend increase is significantly positive. This result suggests that the positive correlation between dividend increases and stock prices is stronger in growing firms and weaker in mature firms.

Grullon, Michaely, Swaminathan (2002) find a permanent increase in the dividend pay-out ratios of dividend-increasing firms. This means that these firms can maintain higher dividends, consistent with Lintner's (1956) finding that managers attempt to smooth dividends. Following these findings, Grullon et al. (2002) propose the maturity hypothesis, positing that a firm tends to increase dividends when moving to a more mature phase from a growth phase. As we know, when a growth firm transforms into a mature firm, its investment opportunities decline, which, in turn, would lead to an increase in the firm free cash flows. A mature firm then pays out these free cash flows in the form of dividends or share repurchases. Therefore, a dividend increase may signal a change in the firm's fundamentals and a commitment of management not to overinvest.

DeAngelo, DeAngelo, and Stulz (2006) say that the life-cycle theory offers a more plausible explanation for the massive payouts. According to life-cycle theory, firms pay dividends when the agency and other retaining cash flow costs exceed the flotation cost and other retention benefits. DeAngelo, DeAngelo, and Stulz (2006) also say that the agency cost-inclusive life-cycle theory most powerfully explains the dividend decisions of the largest longstanding dividend payers because of their choice to distribute substantial dividends consistently over long horizons. With flotation costs and/or asymmetric information problems, as in Myers and Majluf's (1984) pecking order theory, managers will distribute the total value of the free cash flow stream over the life of the enterprise. However, they will distribute nothing until the probability is zero that unanticipated attractive new investments might force them to seek outside capital. In principle, such asymmetric information problems can cause firms to sacrifice dividends entirely until their lives' final period(s).

Life-cycle theory suggests a trade-off between the advantages and disadvantages of the retention of earnings, which varies over the firm's life. The growing firms with abundant investment opportunities should prioritize retained earnings (RE) rather than return cash to shareholders in preparation for necessary investment for their future growth. When firms mature, they become more profitable and internally generate cash in excess of their investment requirements. Dividend-increasing firms do not increase their capital expenditures in the years after dividend increases. The life-cycle theory offers a more plausible explanation for the massive payouts. In that theory, firms pay dividends when 
the agency and other costs of retaining free cash flow exceed the flotation cost and other retention benefits.

\subsection{Catering Theory of Dividend Policy}

The catering theory of dividends was developed by Baker and Wurgler (2004). Their main argument was that managers usually modify corporate payout policies speculatively when investor sentiment favours the payment of dividends (Ferris, Jayaraman and Sabherwal, 2009). At the same time, Baker and Wurgler (2004) provide a catering explanation for the unexpected reductions in the percentage of dividend-paying firms within the U.S. Li, and Lie (2006) provide further confirmation of catering effects among U.S. firms through an examination of changes in corporate payout ratios and their relation to the market dividend premium.

The international presence of dividend catering theory is limited, and its findings are mixed (Ferris, Jayaraman and Sabherwal, 2009). However, Ferris, Sen and Yui (2006) documented that in the U.K., a shift in catering incentives most likely explains the declining inclination to pay dividends over the 1998-2002 sub-period. On the other hand, Eije and Megginson (2008) have done a test over fifteen European countries over the 1989-2003 period and failed to find evidence of catering in their sample. Among all other findings, their findings are recognised best because their regression specifications are substantially different from those estimated by Baker and Wurgler (2004b). After that, Denis and Osobov (2008) ran their estimation over six countries and reported that some of their findings appear inconsistent with dividend catering. They report that the percentage of dividend payers is reduced unexpectedly in those countries where the dividend premium is mainly positive. The reason behind these reduced dividend payers is lower rates of dividend initiations by newly listed firms. However, they do not; formally test for the presence of dividend catering.

The dividend catering theory (Baker \& Wurgler, 2004; Li \& Lie, 2006) suggests that firms pay dividends to cater to investors' demand. Studies on dividend tax reforms (e.g., Hanlon \& Hoopes, 2014; Jacob \& Michaely, 2017; Li et al., 2017) show that a dividend increase (decrease) after a dividend tax cut (increase), providing empirical evidence consistent with this theory. Xu et al. (2021) find that firms increase dividend payouts after controlling shareholders demand higher dividends after the dividend tax reform. Firms pay higher dividends when facing increased demand from controlling shareholders than when the demand is from minority investors. Berzins et al. (2019) also find a reduced dividend-tax sensitivity for firms with more conflicts of interest. Dividends drop less for firms with higher potential conflicts between controlling and minority shareholders after Norway's dividend tax rate increase.

Ferris, Jayaraman and Sabherwal's (2009) attempt was more ambitious than anybody else. They tried to examine dividend catering by using a dataset of 23 countries over the 1995-2004 sample period. The sample was a broad cross-section with both standard and civil law countries which directed them to investigate how differences in the level of shareholder protection might influence the supply of dividends provided by corporate managers. On top of that, the ten years of time-series data allowed them to test changing values of the market dividend premium and determine the degree to which catering might influence global dividend policies. 
La Porta et al. (1997) reported that shareholders in common law countries enjoy more investor protections than civil law countries. La Porta et al. (1999, 2000), Denis and McConnell (2003), and others detect that this legal enfeeblement of shareholders leads to an agency conflict between agents and principals.

According to the catering, theory managers would opportunistically modify corporate payout policies when investor sentiment favours the payment of dividends. Some of the studies have found evidence supporting the catering theory, while some others have not.

\subsection{Free Cash Flow Hypothesis and Dividend Policy}

According to Jensen (1986), the free cash flow hypothesis is why firms pay dividends because it explains dividends to mitigate the agency cost of free cash flows. The free cash flow hypothesis is based on the persisting argument that managers and shareholders have a conflict of interest. Because managers allocate the firm's resources and assets for their benefit rather than act for the shareholder's best interest (Jensen and Meckling, 1976). Managers often spend resources on luxurious offices and unjustifiable mergers and acquisitions. Overinvestment in negative NPV projects is the most common example of managers' selfish behaviour. Easterbrook (1984) and Jensen (1986) suggest that firms return excess cash to shareholders by paying dividends or repurchasing shares to mitigate the overinvestment problem.

The free cash flow hypothesis proposes that cash-rich firms, mature with scarce investment opportunities, always face overinvestment problems. A dividend increase announcement by these firms should be convoyed with a positive stock market reaction because then shareholders will realise that management is not wasting corporate cash flows. Lang and Litzenberger (1989) test the free cash flow hypothesis using Tobin's $Q$ ratio to determine the group of overinvesting firms. They use a sample of 429 regular dividend changes firms between 1979 and 1984. They end up with the result that the average announcement return of significant dividend change is significantly higher for firms with low Tobin's $Q$ than for firms with high Tobin's $Q$. This evidence is consistent with the free cash flow hypothesis that dividend increases by overinvesting firms signal management's intention to mitigate the overinvestment problem, thereby causing a more significant stock market reaction (Thanatawee, 2011).

On the other hand, Howe, He, and Kao (1992) find no significant association between announcement returns and Tobin's $Q$ when examining 55 self-tender offers and 60 special dividend announcements between 1979 and 1989. Again, they run regression between the announcement returns and the firm's cash flow before the event and an interaction term between Tobin's $Q$ and cash flow. However, their findings offer no evidence supporting the free cash flow hypothesis (Thanatawee, 2011). Yoon and Stark (1995) find that the average abnormal return of low- $Q$ firms is significantly higher than that of high- $Q$ firms for dividend increases when they examine a sample of 4,179 dividend changes between 1969 and 1988. However, stock price reactions between these two groups after controlling for the dividend change, dividend yield, and firm's market value were the same. The free cash flow hypothesis argues that dividends are to mitigate agency costs of free cash flows. The free cash flow hypothesis is based on the argument that managers and shareholders have a conflict of interest. Managers always allocate the firm's resources to benefit themselves rather than act for the shareholder's best interest. The average announcement return in response to large dividend change is significantly higher for firms with low Tobin's $Q$ than firms with high Tobin's $Q$. 


\subsection{Firm Life Cycle Theory on Corporate Dividend}

The firm life cycle theory of dividends is based on a firm matures, its ability to generate cash, and, more importantly, its ability to find out profitable investment opportunities. If a firm has free cash flow, it is the firm's paramount duty to distribute its free cash flow to shareholders in dividends (Bulan and Subramanian, 2008).

Accordingly, Mueller (1972) proposed that a firm has a relatively well-defined life cycle, which is fundamental to the firm life cycle theory of dividends. His focus is on the agency problem, whether the managers of a firm work to maximize shareholder value or pursue growth for the firm's own sake and overinvest in assets by overlooking shareholder interests. Drawing on the work of Knight (1921) and Schumpeter (1934), Mueller (1972) posits that a firm originates in an attempt to exploit an innovation involving a new product, process, or marketing or organizational technique.

In the initial stages, all kind of firms invests their all-available resources in developing the innovation and improving its profitability. According to Bulan and Subramanian (2008), the agency problem is either absent or not significant for three reasons at these initial stages. "First, the firm faces so many opportunities for profitable investment that the pursuit of growth is also consistent with the pursuit of profits. Second, unable to meet all its financing needs through internal cash generation, the firm is forced to tap external capital markets. It is therefore subject to market monitoring and discipline. Third, the entrepreneur or manager still retains a sufficiently high fraction of the firm's shares for his or her interests to be well aligned with those of the other suppliers of capital" (Bulan and Subramanian, 2008).

\subsection{Pecking Order Theory and Dividend Policy}

Pecking order theory is based on Myers (1984) and Myers and Majluf (1984). They argue that in the existence of asymmetric information, a firm will follow a pecking order in their financing, in which a firm would prefer internal source of financing to external source of financing alternatives, and that a firm adjusts its target dividend payout to its investment opportunities (Al-Najjar, 2011). In the Hierarchy theory (pecking order theory), the following assumptions are taken- first. Entrepreneurs prefer to finance their activities with internal sources, such as net profit less dividends, depreciation allowances and revenue from the sale of short-term securities and other redundant assets. Furthermore, the second assumption is that when it is necessary to finance activities with debt capital, debt securities are issued first, followed by new shares (Duliniec,1998; Quan, 2002 and Mazur, 2007).

According to pecking order theory, entrepreneurs usually look for the cheapest sources of activity financing to minimise their risk and limit the costs of equity issues or payment of interest on credits and loans they have taken. If necessary, to use the debt capitals, debt securities are issued first (McManus, Gwilym and Thomas, 2006; Duliniec, 2007). Due to that reason, there is a competition between decisions on reinvestment of achieved profit and payment of dividends. Al-Najjar (2011) says that if the retained earnings are insufficient, the firm will borrow rather than issue new stocks, which causes the debt ratio to increase. Whereas Myers (1984) argues that firms prefer debt financing rather than issuing equity, debt financing has lower information costs. That is why the last option for the firm is to issue stock. 


\subsection{Dividend-Signalling Theory and Dividend Policy}

The basis of signalling theory derives from a study by Lintner (1956), in which 28 companies' managers were interviewed to find out which factors were most instrumental in firms' payout policies. Models of dividend-signalling (e.g. Bhattacharya, 1979; John and Williams, 1985; Miller and Rock, 1985) suggest that firms employ dividend changes to convey future earnings information. However, empirical studies based on time-series regression analysis (e.g. Watts, 1973; Gonedes 1978) suggests that dividend convey very little information about the subsequent earnings of the firms. In 2021 Hasan also finds that dividend changes convey very little information regarding future earnings when using the binary model. However, when he uses the interaction model, he finds no association between dividend changes and future profitability.

A path-breaking paper by Miller and Modigliani (1961) suggested 'the information content of dividends, which means that if managements' future earnings expectations affect their current dividend payout decisions, then dividend changes will convey information to the market regarding future earnings (Tsuji, 2012). Allen and Michaely (2003) formalized this notion in two ways, which are "dividends are used as an ex-ante signal of future cash flow as in Bhattacharya (1979), and dividends supply information regarding earnings as a description of the sources and uses of funds identity as in Miller and Rock (1985)". According to Allen and Michaely (2003), the difference is essential for interpreting empirical results since the second alternative can be considered as stating that the fact that dividends convey information does not necessarily mean that dividends are being used as a signal by managers. Allen and Michaely (2003) also found that the dividend signalling hypotheses included three important implications that had been empirically examined, which are "(1) unexpected dividend changes should be accompanied by stock price changes in the same direction; (2) dividend change should be followed by subsequent earnings changes in the same direction and (3) revisions should follow unexpected changes in dividend in the market's expectations of future earnings in the same direction as the dividend change.

The signalling theory of dividends posits that firms convey their optimism for the future by initiating dividend payments (Hobbs and Schneller, 2012). That convinced Lintner that dividends depend not only on the amount of cash needed to finance projects in the shortterm but also represented management's belief in the sustainability of company earnings over the long term. Due to that reason, managers usually increase or initiate payouts only when they believe that subsequent earnings would be high. John and Williams (JW) (1985) and Miller and Rock (1985) show that the level of dividends signals the level for a firm's cash flow, while Kale and Noe (1990) demonstrate that the level of dividends signals the variance of the firm's cash flow.

Previous empirical evidence suggests that investors are always interested in dividend increases and initiations; the stock prices of firms that initiate dividends tend to increase around the initiation announcement (Asquith and Mullins, 1983; Healy and Palepu, 1988). Similarly, the signalling theory implies that any subsequent decrease or elimination of dividends will be viewed with extreme disfavour by the financial markets (Healy and Palepu, 1988; Michaely et al., 1995; Benartzi et al., 1997).

DeAngelo et al. (2004) report that real dividends' aggregate level increases, but dividends become increasingly concentrated rather than widely distributed. According to the signalling theory, companies send a positive signal to the capital markets about high future 
cash flows and profits using dividend payment initiatives. This signal rests a massage (c.f. Lintner, 1956) that the initiation of dividends represents a commitment to sustained payments. Therefore, firms expecting higher future cash flow to pay dividends are most rewarded by investors at the initial announcement.

Hobbs and Schneller (2012) findings extend DeAngelo and DeAngelo (1990) findings to dividend omissions. They show that firms that are operating performance declining to cease dividend payments quickly after initiation. However, Hobbs and Schneller (2012) do not find evidence for the signalling theory's implication that dividends signal a promising future for the firms that initiate them, which is consistent with Grullon et al. (2005), who find little correlation between changes in dividends and subsequent firm profitability. This suggests that at least based on ex-post performance, the initiation of dividends should convey negative news to the market (Hobbs and Schneller, 2012).

Hobbs and Schneller (2012) find that the firms that become permanent payers perform better than those that become temporary payers, even though this finding is not valid in all the cases because there is evidence that dividend sustainability is directly related to future performance. Given this result and the dominant view that dividend initiation is a positive signal partly because of the implicit suggestion that the payments persist. The critical implication is that firms will try to obtain correct market valuation through dividend signalling only when shares of equity must be sold in the market, either by insiders to satisfy personal cash needs or by the firm to raise investment capital. Then, conditional on this decision to initiate dividends, the dividend level will signal firm quality and result in the correct valuation of the firm's shares.

Models of dividend signalling suggest that firms employ dividend changes to convey future earnings information. Miller and Modigliani (1961) suggested 'the information content of dividends or so-called dividend-signalling theory. Suppose management's future earnings expectations affect their current dividend payout decisions. In that case, dividend changes will convey information to the market regarding future earnings and profitability. There are some studies in favour of this hypothesis and against it.

\section{KEY FACTORS INFLUENCE ON DIVIDEND POLICY}

\subsection{Earnings Influence on Dividend Policy}

For a long time in financial research, the effect of dividends on the valuation of securities has been a controversial subject. Still, researchers are trying to find out the solution to this controversial subject. Since Miller and Modigliani (1961) demonstrated the irrelevance of dividend policy, researchers are attempting to explain market price reaction to firms' dividend decisions from then to till now. The information issues and tax effects have mainly influenced dividend decisions. Information issues have been empirically investigated by examining market reactions to announcements of dividend changes. The effect of differential tax treatments of dividends and capital gains usually has been examined through cross-sectional regression testing the significance of dividend yield in explaining returns.

Arjun and Dale (1983) said that a more effective dividend pay-out strategy impacts an increase in the dividend payout ratio and should be complemented by the decrease in price if taxes on dividends are greater than taxes on capital gains. Generally, dividend increase announcement has a more negligible effect over a short period. However, it is 
consistent with both an information effect and a tax effect. Arjun and Dale (1983) observed that firms that announced an increase in dividends generally had positive abnormal returns. In contrast, firms with a positive dividend change and a decrease in the payout ratio tend to have higher abnormal returns than firms with a positive dividend change and an increase in the payout ratio.

Fairfield (1994) says that "price can alternatively be expressed as a function of capitalized current earnings plus the capitalized present value of changes in future abnormal earnings". Price/earnings equal the capitalization factor plus the capitalized present value of expected growth in abnormal earnings. He also says that firms with temporarily depressed earnings that are expected to increase in the future will have high Price/earnings ratios. Firms with abnormally high current earnings are expected to increase because the earnings multiple relates directly to the expected change in abnormal earnings.

A dividend adjustment is linked to earnings changes because empirical studies that addressed the issue of dividend policy often employed either an event-study methodology (Aharony and Swary 1980, Asquith and Mullins 1983) or time-series regression analysis (Fama and Babiak 1968, Watts 1973, Gonedes, 1978, Lee et al. 1987, Chen and Wu 1998). However, the exciting thing is that the event-study methodology studies usually find a significant relationship between dividends and earning changes. On the other hand, studies based on the time-series regression analysis typically find a weak relation between dividends and earnings changes. The main reason behind this problem is that most of the time series regression studies have focused on the relation between dividends and reported accounting earnings rather than dividends and earning changes. However, Lintner (1956) said that dividend changes are more related to changes in permanent earnings. In the empirical analysis, the use of reported accounting earnings figures rather than permanent earnings figures may have produced the puzzling results documented in previous dividend studies (Jumming, Xu-Ming, Chunchi, 1998).

Dividend changes are positively associated what stock returns in the days surrounding the dividend changes announcement (Aharony and Swary, 1972; Asquith and Mullins, 1983; Kalay and Loewenstein, 1985; and Pettit,1972). According to "the information content of dividend hypothesis" (Miller and Modigliani, 1961), dividend changes generate stock returns because they carry new information about the firm's future profitability. However, Nissim and Ziv (2001) strongly disagree with this hypothesis. They come out with the new evidence that dividend changes are positively related to future earnings, future earnings, and future abnormal earnings.

To determine whether dividend changes convey new information about future profitability, need to estimate expected profitability. Nissim and Ziv (2001) found the same result. Previous research found that dividend changes are not positively related to future earnings changes. Nevertheless, they find a positive relation between dividend changes and future earnings when they extend their experiment. To get that result, they used a different measure of profits: earnings and abnormal earnings. Abnormal earnings are defined as the difference between total earnings and normal earnings, where normal earnings are defined as the required return to the owners based on the cost and level of invested equity (Edwards and Bell, 1961). Future normal earnings resulting from future retained earnings and future net stock issues are irrelevant to the current price. It means that to affect price, the earnings information that dividend changes convey must be about future abnormal earnings rather than future normal earnings. Nissim and Ziv (2001) observed that dividend 
decreases are not related to future profits. In contrast, dividend increases are positively related to the profits, which come from ordinary and abnormal earnings.

Dividend changes are highly correlated with contemporaneous earnings changes (Benartzi et al., 1997). Nissim and Ziv (2001) also find a positive relation between dividend changes and earnings changes due to autocorrelation in the earnings change's series. They also mention that management usually increases dividends when they indicate that future earnings will be higher than anticipated. Value-creating activities influence future earnings, but they are also influenced by actions that are not directly relevant for a current price, such as future retained earnings, stock issues and stock repurchases. Abnormal earnings remove from future earnings the effect of capital contributions, earnings, and dividends between the dividend change year and the future year. After using Jordanian data, Al-Shattarat et al. (2017) found that dividend changes predict future profitability and earnings, in line with the dividend signalling hypothesis. However, on the other hand, using the UK FTSE-350 data Hasan (2021) found that there is very little evidence that dividend changes can predict future profitability.

Brickly (1983), Healy and Palepu (1988), and Aharony and Dotan (1994) provide evidence that an increase in dividends leads to an increase in future earnings. Fama and French (1998a) claim that variables that proxy future expected earnings are relevant in explaining the current dividend payout. Watts (1973) and Gonedes (1978) show there is no relationship between current dividends and future earnings, while the evidence in Benartzi, Michaely, and Thaler (1997) suggests that dividend changes provide information about current and past levels of earnings. These points suggest that dividends may respond both to past prices, which, following MM (1987), act as forecasts of current and future permanent earnings and unexpected current permanent earnings. Garrett and Priestley (2000) found that information about the expected future permanent earnings is captured by lagged stock price, and dividends convey information about current unexpected permanent earnings. They also indicate that only positive changes to unexpected permanent earnings affect the current dividend.

\subsection{Dividend Yield Influence on Dividend Policy}

Higher stock returns are associated with higher dividends, independently of whether income is taxed heavily than capital gain (Litzenberger and Ramaswamy, 1979 and 1982; and Morgan and Thomas, 1998). Lintner (1956) was the first who noted the reluctance to cut dividends; usually, managers are reluctant to make dividend changes, which were likely to be unsustainable, but he observed that dividend changes followed shifts in longrun sustainable earnings. So, it means that shifts in dividend policy may provide information to investors relating to the anticipated future performance of the firm (Bhattacharya, 1979 and 1980). Dividend growth follows a period of unusual earnings growth (DeAngelo et al., 1996; and Benartzi et al., 1997). Those firms that maintain or increase the payout ratio based on increased earnings may be viewed as signalling good news to their investors regarding the earnings growth performance. The effect of declining earnings may be more challenging to interpret because managers believe that the earnings decrease is permanent rather than temporary. Then they may be reluctant to reduce dividends. If so, the payout ratio will increase.

McManus, Gwilym and Thomas (2004) suggest that there is a relationship between the payout ratio and stock returns, dividends, seasonality and size, and this reflects both the importance of earnings-related variables in multi-factor models such as those of Fama and 
French (1992, 1993 and 1996), and the conjecture that this ratio conveys signalling information in addition to the dividend yield. Lamont (1998) finds that for forecasting shorthorizon, both dividend yield and payout ratio have information. In contrast, McManus, Gwilym and Thomas (2004) find that, in explaining returns, the payout ratio has an important influence on the statistical significance of dividend yield and casts doubt on the more implicit signalling interpretations of the returns-yield relationship.

Kim (1985) and Morgan and Thomas (1998) identify a 'U-shaped' relation between the dividend yield and returns: the higher the dividend yield, the higher the returns. This is often referred to as a 'non-linearity in the relation between stock returns and dividend yields. Miller and Scholes (1982) argue that the positive yield-return relation is caused by information bias, while Litzenberger and Ramaswamy (1979 and 1982) suggested that the US tax policies, in punishing dividend income relative to capital gains, have led investors to demand higher before-tax returns on stocks which provide a large proportion of their total return in the form of highly taxed dividends.

Empirical studies in the area of the relation between dividend yield and stock returns typically form portfolios of stocks ranked by dividend yield and firm size on a monthly or annually basis (Keim, 1985; Levis, 1989; and Christie, 1990), and the data is used to estimate a stacked regression model linking returns, dividend yields, seasonality, firm size, among others. Keim (1985) shows that firm's size and return seasonality have an important influence on the empirical relationship between stock returns and dividend yields. However, McManus, Gwilym and Thomas (2004) say that firm size and seasonality influence portfolio returns in the regression context but do not dilute the robust and positive relationship between returns and dividend yield. However, the overall findings cannot be justified by the orthodox explanation of the tax effects mentioned earlier or the clientele effects of Elton and Gruber (1970), Scholz (1992) and Denis et al. (1994). However, it is consistent with the dividend signalling models such as those of Bhattacharya (1979), Miller and Rock (1985) and Michaely et al. (1995).

In the related literature, the role of earnings usually has featured frequently in the form of the price-to-earnings ratio (P/E) or its inverse, earnings yield (E/P). Basu (1977 and1983) concludes that E/P explains the cross-section of average returns, even when controlling for size and beta. Ball (1978) suggests E/P as a proxy for unknown factors in expected returns. Gwilym, Morgan and Thomas (2000) say that dividend stability is inversely correlated with systematic risk. They believe that this relationship holds for low and high dividend-yielding stocks but is stronger when dividend stability is measured by the variability of dividend yield than when cuts in annual dividend payments measure it.

To assess the relevance of dividend stability to the relation between dividend yields and returns, Gombola and Liu (1993) initially replicated the Keim (1985) approach by forming five yield-ranked portfolios and a sixth portfolio containing sixth portfolio stocks with zero dividend yield. They obtain similar results to Keim $(1985,1986)$ in observing a U-shaped pattern of absolute returns as yields fall. High returns were associated with high yielding portfolios and low returns associated with low yielding portfolios. Despite this, the portfolio containing stocks with zero dividend yields outperformed all other portfolios, resulting in a nonlinear yield-return relationship. When Gwilym, Morgan and Thomas (2000) were calculated the risk-adjusted returns using the market model, they observed a linear relationship between systematic risk and return, with estimated beta values rising as yields fall. 
Gwilym, Morgan and Thomas (2000) find that portfolios that have been formed with the highest dividend yield generate significant positive abnormal returns. On the other hand, the portfolios based on the lowest non-zero yield portfolio are the only ones to generate significant negative excess returns. In contrast to Keim (1985) and Gombola and Liu (1993), excess returns on the portfolios formed using zero dividend yield stocks are predominantly negative rather than positive. According to Gwilym, Morgan and Thomas (2000), there is a clear inverse correlation between beta and stability; within a dividend yield portfolio, higher systematic risk is a feature of stocks with a relatively unstable history of dividend payments.

However, it is important to note that the inverse relation between beta and stability does not apply to portfolios comprised of stocks with a zero-dividend yield. This finding holds with both definitions of stability. Gwilym, Morgan and Thomas (2000) find a correlation between dividend stability and beta for all non-zero yield groupings but do not suggest a causal relationship. Dividend signalling is not only a phenomenon, which affects highyielding stocks. Relatively a low level of exposure to systematic risk may be signalling outsiders by combining a stable dividend policy with a relatively low yield. This can be very hefty because a stock's yield is not wholly under the control of its managers. So stocks in industrial sectors that tend to earn a relatively low yield can signal low systematic risk by maintaining dividend stability.

Whether the dividend yield has predictive power for stock market returns remains one of the most debated questions in empirical finance. Nevertheless, Hjalmarsson (2010) investigates the predictability of the dividend-price ratio, earnings-price ratio, short-term interest rate, and term spread concerning stock returns and develops new panel estimation methods. His analysis includes both full sample results and some recursive estimation to illustrate changes over time in predictability. He finds that the short-term rate and the term spread are robust predictors of stock returns in developed economies, with no predictability for earning yield and dividend-to-price ratio.

The belief that dividend yields can predict stock returns largely dates back to research by Campbell and Shiller (1988a, 1988b) and Fama and French (1988). Since then, research has debated whether such predictability exists or whether the findings are spurious, perhaps due to possible non-stationary behaviour within the dividend yield or the short sample sizes used in the empirical work. For a flavour of the debate, Campbell et al. (1997), Campbell and Shiller (2001) and Campbell and Yogo (2006) have provided further supporting evidence. In contrast, several authors have argued against such predictability (Wolf, 2000; Lanne, 2002; Valkanov, 2003; Ang and Bekaert, 2007). More recently, Campbell and Yogo (2006) have argued that the overt rejection of the null of no predictability can arise due to persistence in the regressor variable. Cochrane (2008) has argued that the dividend yield must have predictive power for returns (or dividend growth); otherwise, the dividend yield would be a constant in the context of the present value model.

Chen (2009) has reported that the dividend yield may predict dividend growth and returns across different periods. This is a significant result, as previous work rules out dividend growth predictability (e.g. Cochrane, 2001, 2008). Furthermore, building on Campbell and Yogo (2006) work, Park (2010) argues that in a sub-sample of US data that includes the 1990s, the predictive power of the dividend yield disappears. This is again related to the possible non-stationarity of the dividend yield over this time frame. Finally, Engsted and Pedersen (2010) use long-term annual data, dating back to the 1920s and beyond, for the USA, Sweden, Denmark and the UK. They find that US long-horizon predictability is 
dependent on whether returns and dividend growth are measured in nominal or real terms, with more extraordinary evidence in real terms. They report strong predictability of longhorizon real returns in the right direction for the US postwar period and strong long-horizon predictability of real dividend growth in the wrong direction. In contrast, they report no returns predictability but dividend growth predictability for the Scandinavian markets and mixed results for the UK.

McMillan and Wohar (2013) show that the predictive power of the dividend yield for returns and dividend growth is time-varying. Chen (2009) and Engsted and Pedersen (2010) have argued in favour of dividend growth predictability and indeed argued that the nature of predictability for returns and dividend growth varies over time. While the work of Chen, on the one hand, and Engsted and Pedersen, on the other hand, suggest differences in the exact nature of that time variation, a critical point in this line of research are both that they recognize the existence of such time variation and that predictability for dividend growth does occur. McMillan and Wohar (2013) confirm the existence of dividend growth predictability and that the nature of predictability for returns and dividend growth varies over time.

Dividend growth follows a period of unusual earnings growth. Those firms that maintain or increase the payout ratio in light of increased earnings may be viewed as signalling good news to their investors regarding the earnings growth performance. Researchers found a 'U-shaped' relation between the dividend yield and returns: the higher the dividend yield, the higher the returns. This is often referred to as a "non-linearity in the relation between stock returns and dividend yields. Dividend yield may predict dividend growth as well as returns, although across different periods. On the other hand, some researchers show that the predictive power of the dividend yield for returns and dividend growth is time-varying.

\subsection{Corporate Governance Effect on Dividend Policy}

Several theories have been advanced to unwind Miller and Modigliani's (1961) seminal work on dividend irrelevance assumptions of perfect capital markets. But one critical theory that has been extensively examined in the literature and has received supporting evidence is agency theory. The literature has established that agency considerations play a significant role in payout ratio (Lie, 2000; Aivazian et al., 2003 and 2006; and DeAngelo et al., 2006). As La Porta et al. (2000) summarize, corporate governance can potentially have two opposing effects on payout policies as the mechanism to mitigate agency problems. One possibility is that firms operating under a better corporate governance system pay more dividends because of the pressure from shareholders (outcome model). Alternatively, another possibility is that firms operating under poor governance systems and weaker shareholder rights need to pay higher dividends to maintain a good reputation with shareholders (substitution model). According to Jensen's (1986) agency theory, dividend policy is determined by agency costs arising from the divergence of ownership and control. Due to agency costs, managers may not always adopt a dividend policy that is value-maximising for shareholders. Instead, they may choose a dividend policy that maximises their benefits.

Dividend payouts are argued to reduce agency conflicts by reducing the amount of free cash flow, which could be used by managers for their benefits rather than for maximizing shareholders' wealth (Grossman and Hart, 1980; Easterbrook, 1984; Jensen, 1986; DeAngelo, DeAngelo, and Stulz, 2006). On top of that, dividends help mitigate agency conflicts by exposing firms to more frequent monitoring by the primary capital markets. 
Hasan, F.

Paying dividends increases the probability of new equity being issued more often (Easterbrook, 1984). Under the agency framework, the direct link between corporate governance quality and dividend policy has been extensively examined but yielded mixed evidence (Jiraporn, Kim and Kim, 2011). For example, some previous studies find that solid governance is associated with larger dividend payouts (La Porta, Lopez-de-Silanes, Shleifer, and Vishny, 2000; Michaely and Roberts, 2006; Renneboog and Szilagyi, 2006), while other studies find the opposite (Jiraporn and Ning, 2006; Nielsen, 2006; Officer, 2007; Jo and Pan, 2009).

Corporate governance exists to provide checks and balances between shareholders and management and thus to mitigate agency problems. Hence, firms with better governance quality should incur fewer agency conflicts (Jiraporn, Kim and Kim, 2011). As a result, the quality of corporate governance should have an impact on dividend policy. Todd Mitton (2004) says that the agency theory suggests that outside shareholders prefer over retained earnings because insiders might squander cash retained within the firm. This dividend preference maybe even stronger in emerging markets with weak investor protection if shareholders perceive a greater risk of expropriation by insides in such countries than in developed countries where investors enjoy more protection. La Porta et al. (2000) show that dividend payouts are higher, on average, in countries with stronger legal protection of minority shareholders.

La Porta et al. (2000) documented two agency costs of equity models of dividends, namely, the outcome and substitution models. The outcome model suggests that dividends are an outcome of effective governance, where governance can be either country and/or corporate governance (Mitton, 2004; and Bartram et al., 2012). Given the agency costs associated with free cash flow, shareholders prefer dividends to retained earnings since dividends reduce the pool of funds consumed privately by controlling insiders (Easterbrook, 1984; and Jensen, 1986). In turn, the outcome model suggests that the shareholders with the most extraordinary legal rights (and/or belonging to bettergoverned firms) can extract the largest dividends from firms. Hence, the theoretical prediction of the outcome model is that all else equal, dividend payout increases with the strength of shareholder rights (O'Connor, 2013).

On the other hand, the substitution model predicts that corporate dividend payout decreases with the strength of shareholder rights (O'Connor, 2013). In emerging markets where firm-level bonding mechanisms are few, the substitution model suggests that financially constrained, poorly governed firms pay significant dividends in the hope that these reputation ally-enhancing dividends will reduce their cost of external finance (Benos and Weisbach, 2004). In contrast, well-governed firms that are presumably less financially constrained pay much lower dividends. From La Porta et al. (2000) study, the extant literature has found empirical support favouring both models. For example, Mitton (2004), Brockman and Unlu (2009 and 2011), Chae et al. (2009), Sawicki (2009) (in post-Asian crisis Asia), Shao et al. (2009), Adjaoud and Ben-Amar (2010), Jiraporn et al. (2011), Bartram et al. (2012), and Byrne and O'Connor (2012), all support the view that dividend pay-outs increase with shareholder rights. On the other hand, Jiraporn and Ning (2006), John and Knyazeva (2006), Officer (2007), Chae et al. (2009), Jo and Pan (2009), and Sawicki (2009) (in pre-Asian crisis Asia), uncover evidence which supports the substitution model, i.e., dividend pay-outs decrease with shareholder rights.

Brockman and Unlu (2009) extend the agency costs of equity version of the outcome and substitution models by integrating the agency costs of debt. The result is that the 
theoretical predictions of the agency costs of equity and debt version of the outcome model of dividends are different. Given the agency costs of debt, the outcome model predicts that dividend pay-out increases with the strength of shareholder and creditor rights (O'Connor, 2013). This means that where creditor rights are weak and shareholder rights are substantial, creditors demand, and firms consent to lower dividend payouts to shareholders. In effect, creditors substitute poor legal rights for lower dividends. Using country-level measures of shareholder rights, both Shao et al. (2009) and Byrne and O'Connor (2012) find support favouring this prediction; the outcome model of dividends holds where shareholder and creditor rights are substantial.

O'Connor (2013) examine firm-level measures of shareholder rights, i.e., corporate governance is used in contrast to the country-level measures employed by Shao et al. (2009) and Byrne and O'Connor (2012). Since the predictions of the agency costs of equity and debt version of the outcome model of dividends should hold for both country and corporate measures of shareholder rights. O'Connor (2013) found that the creditors exert a profound influence on corporate dividend policy. O'Connor (2013) says that creditors demand and firms consent to pay lower dividends to their shareholders, where creditors' rights are poorly enforced. Shareholders can use their rights to extract significant dividends from firms. However, they can only do so where shareholders rights and the enforcement of creditors' rights are strong. O'Connor (2013) also mentions that the shareholders of better-governed firms do not appear to extract significant dividends from firms where creditor rights are poorly enforced. O'Connor (2013) said that the outcome model fails to hold irrespective of the strength of creditor rights. On the other hand, the outcome model prevails under vigorous enforcement of creditor rights.

Todd Mitton (2004) said that "if protection of minority shareholders does have a positive impact on dividend payouts, then shareholder protection should help explain not just country-level differences in dividend payouts, but also firm-level differences in dividend payouts within countries". He also suggests that while country-level investor protection is essential in preventing expropriation, firm-level corporate governance could carry equal or greater importance. Moreover, corporate governance practices can vary widely, even among firms in the same country operating under the same legal regime. Todd Mitton (2004) uses firm-specific corporate governance ratings developed by Credit Lyonnais Securities Asia (CLSA) to study the impact of firm-level corporate governance on dividend payouts.

Todd Mitton (2004) also says, when shareholders are well protected, they may not prefer higher dividend pay-outs if they believe that the firm has good investment opportunities available for excess cash. La Porta et al. (2000) found a stronger negative relationship between growth opportunities and dividend payouts in countries with solid investment protection and corporate governance. Todd Mitton (2004) documented that firms with more robust governance have higher profitability. However, improved profitability explains only part of the connection between governance and dividends.

Jiraporn, Kim and Kim (2011) explore the impact of The Jobs and Growth Tax Relief Reconciliation Act 2003 (JGTRRA). JGTRRA reduces the maximum tax rate on dividends and therefore alleviates the tax disadvantage of dividends. They say that this Act makes dividends more attractive as a means of cash disbursement. Jiraporn, Kim and Kim (2011) tests reveal that this legislation does not seem to have a significant impact. Jiraporn, Kim and Kim (2011) argue that the quality of corporate governance affects dividend payout. They also say that corporate governance and dividend policy are endogenously 
determined. For that reason, dividend payout might influence the quality of corporate governance and vice versa.

Dividends and repurchases are parallel because both entail cash disbursement. In recent times, repurchases have become more popular and have replaced dividends in many firms. Nevertheless, one key difference between dividends and repurchases is that repurchases are much more discretionary cash distributions relative to dividends. Prior research shows a strong negative market response to dividend cuts and omissions. Accordingly to Jiraporn, Kim and Kim (2011), dividends significantly constrain managers through the high cost of dividend reduction or discontinuation, making dividends a more effective pre-commitment mechanism in the presence of an agency conflict. By contrast, the flexibility associated with repurchases gives managers much more discretion, thereby diminishing their effectiveness in alleviating the agency conflict. Recent evidence about the difference between dividends and repurchases can be found in Kooli and L'Her (2010). Jiraporn, Kim and Kim (2011) say that in firms with weak governance, managers may avoid paying dividends in favour of repurchases because they can exercise more discretion over repurchase decisions. This result would be consistent with the outcome hypothesis. On the contrary, managers may choose dividends over repurchases in firms with poor governance quality because dividends constitute a robust governance mechanism and send a stronger signal to the capital markets that managers do not expropriate from shareholders (because dividends reduce what is left for expropriation). This result would be consistent with the substitution hypothesis. However, John and Knyazeva (2006) report that more robust governance is associated with a stronger dividend propensity over repurchases.

Jiraporn, Kim and Kim (2011) say that the association between dividend payouts and governance quality is conditional on external financing constraints. Chae, Kim, and Lee (2009) argue that firms with better governance pay larger dividends only when not subject to external financing constraints. On the contrary, when subject to financing constraints, they do not pay out more dividends. Larger dividend layouts increase the likelihood for firms to raise external capital in the future. Therefore, firms with difficulty raising external capital (i.e., those with financing constraints) would be less likely to pay larger dividends. Jiraporn, Kim and Kim (2011) report, firms with more free cash flow are more vulnerable to agency conflict. In addition, they said firms with higher information asymmetry likely incur higher costs when raising external capital, as it is harder for external capital providers to monitor these firms. Jiraporn, Kim and Kim (2011) use the residual volatility of daily stock returns to proxy for information asymmetry; the more volatile, the higher the information asymmetry.

One critical theory that has been extensively examined in the literature and has received supporting evidence is agency theory. It has been established in the literature that agency considerations play a significant role in the payout ratio. Dividend payouts are argued to reduce agency conflicts by reducing the amount of free cash flow, which managers could use for their benefits rather than for maximizing shareholders' wealth. Shareholders of better-governed firms do not appear to extract significant dividends from firms where creditor rights are poorly enforced. In firms with weak governance, managers may avoid paying dividends favouring repurchases because they can exercise more discretion over repurchase decisions. 


\subsection{Capital Structure and Dividend Policy}

For more than 50 years, the search for the optimal sources of activity financing and their share in the capital structure occupied the debate of the greatest minds in economics and finances. An issue that is firmly connected with the choice of financing sources is dividend policy, which also constitutes a broad research area. The issue of the optimal capital structure and the choice of corporate dividend policy remain unsolved. The discussion of capital structure and dividend policy has been a controversial debate in corporate finance for a long time for scholars. Due to that reason, scholars are still interested in investigating using different approaches and applying different techniques to different markets.

This debate starts with the seminal work of Modigliani and Miller (1958). They find that given the perfect market assumptions, capital structure is unrelated to the firm's value. Thus, managers should have no concern about the firm's capital structure when making or taking any financial decisions. But we know that perfect market assumptions will not hold in reality. Therefore it is arguable that Modigliani and Miller (1958) models need modifications. Modigliani and Miller (1958) irrelevance theorem are essential and puzzling issues in modern corporate finance theory, challenging the traditional view that optimum leverage exists (Mondher, 2011).

Later Modigliani and Miller (1963) relaxed their perfect market assumptions and considered corporate tax in their models. Consequently, they find that the firm's value will increase as the debt level increases because interest is tax-deductible. Hence, firms will enjoy a debt tax shield from using debt financing. However, one thing they ignore is bankruptcy costs. The work of Modigliani and Miller in the area of capital structure draws researchers' attention to investigate firms' capital structure. Miller and Modigliani's significantly contribute to the dividend policy literature as well. In 1961 they investigated the theory of dividend policy. They concluded that given the perfect market assumptions, dividend policy is unrelated to the firm's value. They argued that the firm's value depends on the income produced by its assets and not on how it is split between dividend payments and retained earnings. This is called dividend irrelevance theory in the finance literature. Later, scholars challenge the main findings of Miller and Modigliani (1961) since the assumptions of the perfect market will not hold in reality (Al-Najjar, 2011).

In the theory of economics, especially finances, we can notice different approaches described in the theory of substitution and the theory of hierarchy (pecking order theory) to the issue of shaping the most favourable sources of activity financing (FrancDabrowska, 2009). The substitution (trade-off) theory assumes that managers look for debt capital to equity capital ratio that will allow them to achieve maximum business value (Franc-Dabrowska, 2009). The risk connected with financing enterprise activities with debt capital is compensated by tax advantages (Theobald 1979; Duliniec 1998), resulting from the decrease of the tax base by interest forming a cost element (this theory assumes the existence of benefits as a result of the tax shield mechanism). This approach is consistent with the Value-based Management concept (Franc-Dabrowska 2007). Erasmus and Scheepers (2008) discussed the value creation concept, not from the capital structure and dividend point of view but highlighting the importance of innovation and entrepreneurship. The substitution theory pays attention to the different aspects of the firm's activities. However, it pays extraordinary attention to the occurrence of costs of financial difficulties and the fact that an increase of the debt capital share in the financial structure increases the risk of losing financial liquidity and of bankruptcy. 
Any enterprise needs to maintain financial liquidity. Otherwise, the loss of financial liquidity creates a danger of imminent bankruptcy (Franc-Dabrowska, 2009). From the point of view of choosing the most favourable dividend policy, a crucial point highlights the necessity of maintaining financial liquidity (which is essential according to the substitution theory). It cannot be forgotten that any resolution to pay dividends adopted by the management board becomes a binding liability of the company and has to be settled. To this end, it is necessary to collect a certain amount of cash (Ross, Westerfield, and Jordan 2006).

Modigliani and Miller do not consider the effect of bankruptcy costs in their models of capital structure and dividend policy (Modigliani and Miller 1958, 1961and 1963). However, these costs exist in reality and affect financing decisions. Bankruptcy costs exit when a firm's financing decisions, including capital structure, will be restructured. Such transfer is classified into direct costs, including legal and accounting charges, and indirect costs, including the opportunity costs in case of interruption in the firm's suppliers and customers' relations (Haugen and Senbet, 1978). Miller (1970) and Haugen and Senbet (1978) argue that bankruptcy costs are irrelevant in a firm's financing decisions. DeAngelo and Masulis (1980) also did not rely on bankruptcy or agency costs. Their optimal solution rests on the explicit modelling of the non-debt tax shields such as depreciation expenses and investment tax credits (Basil, 2011). However, Titman and Wessels (1988), Holder, Langrehr, and Hexter (1998), Booth et al. (2001), Bhaduri (2002), Ho (2003), Aivazian, Booth, and Cleary (2003) and Huang and Song (2006) find a significant effect of business risk as an indicator for financial distress and bankruptcy in capital structure and dividend policy decisions.

Dividend policy is directly connected with capital structure theories because dividend policy is one of the determinants of capital structure-firms with a reputation for paying dividends faceless asymmetric information when they enter the equity market. Dividend payment represents a signal of improved financial health and more debt-issuing capacity (Bhaduri 2002; John and Williams 1985; Miller and Rock 1985). This argument is supported by the signalling theory of capital structure (Al-Najjar, 2011). Easterbrook (1984) documents that dividends exist because they induce firms to float new securities suggesting that a firm's dividend decisions are linked to its financing decisions. Intuitively, it is clear that the firm's payout ratio determines its retention ratio and, thus, its capital structure. Thus, a positive relationship is expected between dividend policy and capital structure. On the other hand, capital structure is a determinant of dividend policy. Therefore, a positive relationship is expected between dividend policy and capital structure.

When an enterprise pays dividends, it automatically decreases the degree of equity capital financing from its internal sources. As a consequence, it may require external financing sources (Franc-Dabrowska, 2009). The theory of Modigliani and Miller indicating the neutrality of dividend policy for the value of the company was hedged around with assumptions that are far from reality (Modigliani and Miller 1961; 1963). Corporate debt levels should be related to the cash flows retained by a firm and to its dividend policy. Indeed, because of the interdependence between dividend policy and capital structure, empirical studies of capital structure, including those that focus on the impact of firm multinationality, are most likely misspecified unless they include an assessment of dividend policy (Aggaarwal and Kyaw, 2010). 
Adedeji (1998) suggests that if firms borrow to pay dividends because they do not want to or they are reluctant to cut dividends, then the financial leverage may have a positive relationship with the dividend payout ratio and may have a positive or negative relationship with investments depending on whether firms borrow to finance investments or postpone/reduce the investments. This hypothesized positive relationship between debt and dividend payout is empirically confirmed in Baskin (1989). Thus, according to the pecking order hypothesis, corporate capital structure is positively related to its dividend policy. On the other hand, Jensen (1986) hypothesizes that dividends and debt are substitute mechanisms for controlling agency costs of free cash flows. The empirical finding of Agrawal and Jayaraman (1994) supports Jensen's hypothesis. They find that dividend payout ratios of a sample of all equity firms are significantly higher than those of a control group of levered firms. Jensen et al. (1992) posit that firms with high dividend payouts usually find debt financing less attractive than equity financing leading to a negative relationship between debt and dividends. As noted in the comprehensive survey on payout policy by Allen and Michaely (2002), firms also might not want to pay high dividends when they are obligated to pay high levels of other fixed finance charges.

The discussion of capital structure and dividend policy is a controversial debate in corporate finance that scholars were and still are interested in investigating using different approaches and applying different techniques into different markets. Capital structure is unrelated to the value of the firm. Hence, managers should have no concern about a firm's capital structure when making financial decisions. An essential aspect that cannot be omitted in any deliberations concerning the financial situation of enterprises is the necessity of maintaining financial liquidity, the loss of which creates a danger of imminent bankruptcy. Dividend policy is directly connected with capital structure theories because dividend policy is one of the determinants of capital structure-firms with a reputation for paying dividends faceless asymmetric information when they enter the equity market. Dividend payment represents a signal of improved financial health, and hence of more debt-issuing capacity.

\section{IMPLICATION AND CONCLUSION}

\subsection{Implication}

The main contribution of this paper is that it added a new dimension to the current literature through analysing different dividend policy theories and dividend policy elements. In this research paper, we show how different theories are associated with a firm's dividend policy. Whenever firms paying their dividends, they do it based on these theories. Also, this paper gives a clear idea to the researchers that how dividend orthodox (Corporate) finance elements are directly associated with the dividend policy of the firms.

\subsection{Conclusion}

This paper is based on the relationship between orthodox finance and dividend policy. In this paper, I have discussed the relationship between the different dividend theories and dividend policy. Also, I have discussed the key factors that influence dividend policy. For a long time, researchers have been trying to solve the dividend puzzle using different dividend theories and using different variables. However, so far, there seems to be no clear solution. 
According to Modigliani and Miller, in the perfect capital market, dividend payout policy is irrelevant. On the other hand, in imperfect markets, dividend policy can affect investment decisions. When managers have more information about the firm's assets value and investment projects than outside investors, other problems can constrain the firm's access to external funds. In comparison, life-cycle theory suggests that the trade-off between the advantages and disadvantages of earnings retention varies over the firm's life. According to Baker and Wurgler (2004), managers would opportunistically modify corporate payout policies when investor sentiment favours the payment of dividends.

As we know after Modigliani and Miller's dividend irrelevancy theory (1958 and 1961), several different theories have immerged, but among them, dividend signalling theory or so-called 'information content of dividend' theory (Bhattacharya, 1979; Miller and Rock, 1985 ) is the most prominent one. Several types of research have been conducted based on this theory to solve the dividend puzzle. Even though the researchers also used other dividend-related theories to solve the dividend puzzle, no other theories got that much attention, like the dividend signalling theory.

\section{REFERENCES}

Abeyratna, G., Lonie, A., Power, D. and Sinclair, C. (1996). The influence of company financial performance on the interpretation of dividend and earnings signals: a study of accounting- and market-based data. British Accounting Review, 28, pp. 229-247.

Adedeji, A. (1998). Does the pecking order hypothesis explain the dividend payout ratios of firms in the UK?. Journal of Business, Finance and Accounting, 25 (9-10), pp. 1127-1155.

Adjaoud, F. and Ben-Amar, W. (2010), Corporate governance and dividend policy: shareholders' protection or expropriation?. Journal of Business Finance \& Accounting, 37(5-6), pp. 648-667.

Agrawal, A. and Jayaraman, N. (1994). The dividend policies of all-equity firms: A direct test of the free cash flow theory. Managerial and Decision Economics, 15(2), pp. 139-148.

Aggarwal, R. and Kyaw, N. A. (2010). Capital structure, dividend policy, and multinational: Theory versus empirical evidence. International Review of Financial Analysis, 19, pp. 140-150.

Aharony, J. and Swary, I. (1980). Quarterly dividend and earnings announcements and stockholders' returns: An empirical analysis. Journal of Finance, 35, pp.1-12.

Aharony, J. Falk, H. and Swary, I. (1988). Information content of dividend increases: the case of regulated utilities. Journal of Business, Finance and Accounting, 15(3), pp.401-414.

Aharony, J. and Dotan, A. (1994). Regular dividend announcements and future unexpected earnings: An empirical analysis. Financial Review, 29, pp.125-151.

Aivazian, V., Booth, L. and Cleary, S. (2003). Dividend policy and the organization of capital markets. Journal of Multinational Financial Management, 13(2), pp. 101-121.

Aivazian, V., Booth, L. and Cleary, S. (2006). Dividend smoothing and debt rating. Journal of Financial and Quantitative Analysis, 41(2), pp. 439-453.

Allen, F. and Michaely, R. (1995). In R. A. Jarrow, V. Maksimovic, and W.T. Ziemba (Eds.), Dividend policy Handbooks in operations research and management science, 9, pp.793-837.

Allen, F. and Michaely, R. (2003). Payout policy. In: George Constantinides, Milton Harris, \& Rene Stulz (Eds.), North-Holland Handbook of Economics, New York: North-Holland.

Al-Najjar, B. (2011). The inter-relationship between capital structure and dividend policy: empirical evidence from Jordanian data. International Review of Applied Economics, 25(2), pp.209-224.

Ang, A. and Bekaert, G. (2007). Stock return predictability: is it there?. Review of Financial Studies, 20, pp. 651-707.

Arjun, D. and Dale, M. (1983). Market responses to dividend increases and changes in payout ratios. Journal of Financial and Quantitative Analysis, 18(2), pp. 163-173.

Asquith, P. and Mullins, D. W. Jr. (1983). The impact of initiating dividend payments on shareholders' wealth. Journal of Business, 56(1), pp.77-96.

Asquith, P. and Mullins, D. W. Jr. (1986). Signalling with dividends, stock repurchases, and equity issues. Financial Management, 15, pp.27-44.

Ball, R. (1978). Anomalies in relationships between securities' yields and yield surrogates. Journal of Financial Economics, 6, pp. 103-26.

Baker, M. and Wurgler, J. (2002). Market timing and capital structure. Journal of Finance, 57, pp.1-32.

Baker, M. and Wurgler, J. (2004(a)). A catering theory of dividends. Journal of Finance, 59, pp.1125-1165. 
Baker, M. and Wurgler, J. (2004(b)). Appearing and disappearing dividends: the link to catering incentives. Journal of Financial Economics, 73, pp.271-288.

Bartram, S., Brown, P., How, J. and Verhoeven, P. (2012), Agency conflicts and corporate payout policies: a global study. Working Paper, Lancaster University.

Baskin, J. (1989). An empirical investigation of the pecking order hypothesis. Financial Management, 18(1), pp. 26-35.

Basu, S. (1977). Investment performance of common stocks in relation to their price-earnings ratios: A test of the efficient markets hypothesis. Journal of Finance, 32(3), pp. 663-82.

Basu, S. (1983), The relationship between earnings yield, market value, and return for NYSE common stocks: further evidence. Journal of Financial Economics, 12, pp. 129-56.

Benos, B. and Weisbach, M. (2004). Private benefits and cross-listings in the United States. Emerging Markets Review, 5(2), pp. 217-240.

Benartzi, S., Michaely, R. and Thaler, R. (1997). Do changes in dividends signal the future or the past. The Journal of Finance, 52(3), pp.1007-1034.

Berzins, J., Bohren, O. and Stacescu, B. (2019). Dividends and taxes: The moderating role of agency conflicts. Journal of Corporate Finance, 58, pp. 583-604.

Bhaduri, S. (2002). Determinants of corporate borrowing: Some evidence from the Indian corporate structure. Journal of Economics and Finance, 26, pp. 200-215.

Bhattacharya, S. (1979). Imperfect information, dividend policy and the "Bird in the Hand" fallacy. Bell Journal of Economics and Management Science, 10, pp.259-70.

Bhattacharya, S. (1979). Nondissipative signalling structures and dividend policy. Quarterly Journal of Economics, 95, pp.1-24.

Bhattacharyya, N. (2007). Dividend policy: a review. Managerial Finance, 33(1), pp.4-13.

Booth, L., Aivazian, V., Demirguc-Kunt, A. and Maksimovic, V. (2001). Capital structures in developing countries. Journal of Finance, 56(1), pp. 87-130.

Brickley, J. (1983). Shareholder wealth, information signalling, and the specially designated dividend: An empirical Study. Journal of Financial Economics, 12, pp. 187-209.

Bozos, K., Nikolopoulos, K. and Ramgandhi, G. (2011). Dividend signalling under economic adversity: evidence from the London Stock Exchange. International Review of Financial Analysis, 20, pp.364-374.

Brockman, P. and Unlu, E. (2009). Dividend policy, creditor rights, and the agency costs of debt. Journal of Financial Economics, 92(2), pp. 276-299.

Brockman, P. and Unlu, E. (2011). Earned/contributed capital, dividend policy, and disclosure quality: an international study. Journal of Banking and Finance, 35(7), pp. 1610-1625.

Bulan, L.T. and Subramanian, N. (2008). The firm life cycle theory of dividends, The Blackwell Companion to Dividends and Dividend Policy, H. Kent Baker (ed.), Blackwell.

Byrne, J. and O'Connor, T. (2012). Creditor Rights and the Outcome Model of Dividends. The Quarterly Review of Economics and Finance, 52(2), pp. 227-242.

Campbell, J. Y. and Shiller, R. J. (1988(a)). The dividend-price ratio and expectations of future dividends and discount factors. Review of Financial Studies, 1, pp. 195-227.

Campbell, J. Y. and Shiller, R. J. (1988(b)). Stock prices, earnings, and expected dividends. Journal of Finance, 43, pp. 661-676.

Campbell, J. Y. and Shiller, R. J. (2001). Valuation ratios and the long-run stock market outlook: an update. NBER Working Paper 8221.

Campbell, J. Y. and Yogo, M. (2006). Efficient tests of stock return predictability. Journal of Financial Economics, 81, pp. 27-60.

Campbell, J. Y., Lo, A. W. and MacKinlay, C. (1997). The Econometrics of Financial Markets, Princeton, NJ: Princeton University Press.

Chae, J., Kim, S. and Lee, E. (2009). How corporate governance affects payout policy under agency problems and external financing constraints. Journal of Banking and Finance, 33, pp. 2093-2101.

Chan, C. and Wu, C. (1998). The dynamic of dividends, earnings and stock price: Evidence and implication for dividend smoothing and signalling. Journal of Empirical Finance, 6(1), pp. 29-58.

Chen, L. (2009). On the reversal of return and dividend growth predictability: a tale of two periods. Journal of Financial Economics, 92, pp. 128-151.

Cochrane, J. (2001). Asset Pricing, Princeton, NJ: Princeton University Press.

Cochrane, J. H. (2008). The dog that did not bark. A defence of return predictability. Review of Financial Studies, 21, pp. 1533-1575.

Christie, W.G. (1990). Dividend yield and expected returns: the zero-dividend puzzle. Journal of Financial Economics, 28, pp. 95-125.

Christie, W.G. (1994). Are dividend omissions truly the cruellest cut of all?. Journal of Financial and Quantitative Analysis, 29(3), pp. 459-480.

DeAngelo, H., DeAngelo, L, and Stulz, R.M. (2006). Dividend policy and the earned/contributed capital mix: A test of the life-cycle theory. Journal of Financial Economics, 81, pp.227-254. 
DeAngelo, H. and DeAngelo, L., Skinner, D. (1996). Reversal of fortune dividend signalling and the disappearance of sustained earnings growth. Journal of Financial Economics, 40, pp.341-371.

DeAngelo, H. and DeAngelo, L., Skinner, D. (2000). Special dividends and the evaluation of dividend signalling. Journal of Financial Economics, 57, pp.309-354.

DeAngelo, H. and DeAngelo, L., Skinner, D. (2004). Are dividends disappearing? Dividend concentration and the consolidation of earnings. Journal of Financial Economics, 72, pp.425-456.

DeAngelo, H. and DeAngelo, L. (2006). The irrelevance of the MM dividend irrelevance theorem. Journal of Financial Economics, 79, pp.293-315.

DeAngelo, H. and Masulis, R.W. (1980). Optimal capital structure under corporate and personal taxation. Journal of Financial Economics, 8, pp. 3-29.

Denis, D. J. (1990). Defensive changes in corporate payout policy: share repurchases and special dividends. The Journal of Finance, 45(5), pp.1433-1456.

Denis, D.J., Denis, D.K., and Sarin, A. (1994). The information content of dividend changes: cash flow signalling, overinvestment, dividend clienteles. Journal of Financial and Quantitative Analysis, 29, pp.567-587.

Denis, D. K. and McConnell J.J. (2003). International corporate governance, Journal of Financial and Quantitative Analysis, 38(1), pp.1-36.

Denis, D.J. and Osobov, I. (2008). Why do firms pay dividends? International evidence on the determinants of dividend policy. Journal of Financial Economics, 89, pp.62-82.

Duliniec, A. (1998). Struktura i koszt kapitału w przedsi ebiorstwie. Warsaw: Wydawnictwo Naukowe pwn.

Duliniec, A. (2007). Finansowanie przedsi ebiorstwa, Warsaw: Polskie Wydawnictwo Ekonomiczne.

Easterbrook, F.H. (1984). Two Agency-Cost Explanation of Dividends. American Economic Review, 74, pp.650-659.

Edwards, E. O. and Bell, P. W. (1961). The Theory and Measurement of Business Income, Berkeley and Los Angeles, CA: University of California Press.

Eije, H. V. and Megginson, W. L. (2008). Dividends and share repurchases in the European Union, Journal of Financial Economics, 89(2), pp.347-374.

Elton, E. J. and Gruber, M. J. (1970). Marginal stockholder tax rates and the clientele effect. The Review of Economics and Statistics, 52(1), pp.68-74.

Engsted, T. and Pedersen, T. Q. (2010). The dividend-price ratio does predict dividend growth: international evidence. Journal of Empirical Finance, 17, pp. 585-605.

Erasmus P. and Scheepers, R. (2008). The relationship between entrepreneurial intensity and shareholder value creation. Managing Global Transitions, 6(3), pp. 229-56.

Fama, E. and Babiak, H. (1968). Dividend policy: An empirical analysis. Journal of the American Statistical Association, 63(324), pp. 1132-1161.

Fama, E. and Miller, M. (1972). The Theory of Finance. Hinsdale, IL: Dryden Press.

Fama, E. F. and French, K. R. (1988). Dividend yields and expected stock returns. Journal of Financial Economics, 22, pp.3-25.

Fama, E. F. and French, K. R. (1992). The cross-section of expected stock returns. Journal of Finance, 47(2), pp. 427-65.

Fama, E. F. and French, K. R. (1993). Common risk factors in the returns on stocks and bonds. Journal of Financial Economics, 33, pp. 3-56.

Fama, E. F. and French, K. R. (1996). Multifactor explanations of asset pricing anomalies. Journal of Finance, 51, pp. 55-84.

Fama, E. F. and French, K. R. (1998). Value versus growth: the international evidence. Journal of Finance, 53(6), pp. 1975-99.

Fama, E. F. and French, K. R. (2001). Disappearing dividends: changing firm characteristics or lower propensity to pay?. Journal of Financial Economics, 60, pp.3-43.

Fairfield, P.M. (1994). P/E, P/B and the present value of future dividends. Financial Analysts Journal, pp. 2331.

Ferris, S. P., Sen, N. and Unlu, E. (2009). An international analysis of dividend payment behaviour. Journal of Business Finance \& Accounting, 36(3-4), pp.496-522.

Ferris, S. P., Noronha, G. and Unlu, E. (2010). The more, the merrier: an international analysis of the frequency of dividend payment. Journal of Business Finance \& Accounting, 37(1-2), pp.148-170.

Ferris, S. P., Sen, N. and Yui, H. P. (2006). God save the queen and her dividends: Corporate payouts in the UK. Journal of Business, 79, pp.1149-1173.

Franc-Dabrowska, J. (2009). Does dividend policy follow the capital structure theory?. Managing Global Transitions, 7 (4), pp. 367-382.

Garret, I. and Priestley, R. (2000). Dividend behaviour and dividend signalling. Journal of Financial and Quantitative Analysis, 35(2), pp.173-189.

Gombola, M. J. and Liu, F.Y. (1993). Considering dividend stability in the relation between dividend yields and stock returns. Journal of Financial Research, 16, pp. 139-50. 
Gonedes, N.J. (1978). Corporate signalling, external accounting, and capital market equilibrium: evidence on dividends, income, and extraordinary items. Journal of Accounting Research, 16, pp.26-79.

Gombola, M. J. and Liu, F.Y. (1993). Considering dividend stability in the relation between dividend yields and stock returns. Journal of Financial Research, 16, pp.139-50.

Gordon, M. J. (1963). Optimal investment and financing policy. The Journal of Finance, 18(2), pp.264-272.

Gorman, L. R., Weigand, R. A. and Zwirlein, T. J. (2004). The information content of dividend resumptions. Studies in Economics and Finance, 22(2), pp.70-99.

Graham, J. R. (1996). Debt and the marginal tax rate. Journal of Financial Economics, 41, pp.41-73.

Graham, F. and Isaac, A.G. (2002). The behavioural life-cycle theory of consumer behaviour: Survey evidence. Journal of Economic Behavior \& Organization, 48, pp.391-401.

Graham, J. R. and Tucker, A. L. (2006). Tax shelters and corporate debt policy, Journal of Financial Economics, 81, pp.563-594.

Grossman, S.J. and Hart, O.D. (1980). Takeover bids, the free-rider problem, and the theory of the corporation. Bell Journal of Economics, 11, pp. 42-54.

Griffin, P. A. (1976). Competitive information in the stock market: an empirical study of earnings, dividends and analysis' forecasts. The Journal of Finance, 31(2), pp.631-650.

Grinblatt, M., Masulis, R.W. and Titman, S. (1984). The valuation effects of stock splits and stock dividends. Journal of Financial Economics, 13, pp.97-112.

Grossman, S.J. and Hart, O.D. (1980). Takeover bids, the free-rider problem, and the theory of the corporation. Bell Journal of Economics, 11, pp.42-54.

Grullon, G., and Michaely, R. (2002). Dividends, share repurchases, and the substitution hypothesis. The Journal of Finance, 57, pp.1649-1684.

Grullon, G., Michaely, R. and Swaminathan, B. (2002). Are dividend changes a sign of firm maturity?. The Journal of Business, 75, pp.387-424.

Grullon, G., Michaely, R., Benartzi, S. and Thaler, R. H. (2005). Dividend changes do not signal changes in future profitability. Journal of Business, 78(5), pp.1659-1682.

Hanlon, M. and Hoopes, J. L. (2014). What do firms do when dividend tax rates change? An examination of alternative payout responses. Journal of Financial Economics, 114 (1), pp. 105-124.

Hasan, F. (2021). Dividend changes as predictors of future profitability. The Journal of Prediction Markets. 15(1), pp. 37-66.

Haugen, R. A. and Senbet, L. W. (1978). The insignificance of bankruptcy costs to the theory of optimal capital structure. Journal of Finance, 33, pp. 383-393.

Haugen, R. A. and Senbet, L. W. (1986). Corporate finance and taxes: a review. Finance Manage, 15, pp. 521.

Hauser, R. (2013). Did dividend policy change during the financial crisis? Managerial Finance, 39(6), pp. 584606.

Healy, P. M. and Palepu, K. G. (1988). Earnings information conveyed by dividend initiations and omissions. Journal of Financial Economics, 21, pp.149-175.

Hjalmarsson, E. (2010). Predicting global stock returns. Journal of Financial and Quantitative Analysis, 45, pp. 49-80.

Ho, K. S. and Wu, C. (2001). The earnings information content of dividend initiations and omissions. Journal of Business Finance and Accounting, 28(7-8), pp. 963-977.

Ho, H. (2003). Dividend policies in Australia and Japan. International Advances in Economic Research, 9(2), pp. 91-100.

Hobbs, J. and Schneller, M. I. (2012). Dividend signalling and sustainability. Applied Financial Economics, 22, pp.1395-1408.

Holder, M.E., Langrehr, F.W. and Hexter. J.L. (1998). Dividend policy determinants: an investigation of the influences of stakeholder theory. Financial Management, 27(3), pp. 73-82.

Howe, K. M., He, J., and Kao, G. W. (1992). One-time cash flow announcements and free cash flow theory: share repurchase and special dividends. Journal of Finance, 47, pp.1963-1974.

Huang, S.G. and Song, F.M. (2006). The determinants of capital structure: Evidence from China. China Economic Review, 17, pp. 14-36.

Ishikawa, H. (2011). Empirical analysis on the dividend life-cycle theory: evidence from Japan. The Japanese Accounting Review, 1, pp.40-60.

Jacob, M. and Michaely, R. (2017). Taxation and dividend policy: The muting effect of agency issues and shareholder conflicts. The Review of Financial Studies, 30 (9), pp. 3176-3222

Jensen, M. and Meckling, W. (1976). Theory of the firm: managerial behaviour, agency costs and ownership structure. Journal of Financial Economics, 3, pp.305-360.

Jensen, M. (1986). Agency costs of free cash flow, corporate finance and takeovers. The American Economic Review, 76, pp.323-329.

Jensen, G. R., Solberg, D. P. and Zorn, T. S. (1992). Simultaneous determination of insider ownership, debt, and dividend policies. Journal of Financial and Quantitative Analysis, 27(2), pp.247-263. 
Jiraporn, P., Kim, Y.S. Davidson, W.N. and Singh, M. (2006). Corporate governance, shareholder rights and firm diversification: An empirical analysis. Journal of Banking and Finance,.30, pp.947-963.

Jiraporn, P. and Ning, Y. (2006), Dividend policy, shareholder rights, and corporate governance. Journal of Applied Finance, 16(2), pp.24-36.

Jirporn, P., Kim, J. and Kim, Y. (2011). Dividend payouts and corporate governance quality: an empirical investigation. The Financial Review, 46, pp.251-279.

Jo, H. and Pan, C. (2009). Why are firms with entrenched managers more likely to pay dividends?. Review of Accounting and Finance. 8, pp. 87-116.

John, K. and Knyazeva, A. (2006). Payout policy, agency conflicts, and corporate governance. Working Paper, New York University.

Julio, B. and Ikenberry, D. L. (2004). Reappearing dividends. Journal of Applied Corporate Finance, 16, pp.89100.

John, K. and Williams, J. (1985). Dividend, dilution, and taxes: a signalling equilibrium. Journal of Finance, 40, pp.1053-1070.

Jumming, H., Xu-Ming, W. and Chunchi, W. (1998). The Role of Earnings Information in Corporate Dividend Decisions. Management Science, 44(12), pp. 173-191.

Kane, A., Lee, Y. and Marcus, A. (1984). Earnings and dividend announcements: Is there a corroboration effect?. Journal of Finance, 39, pp.1091-1099.

Kalay, A. and Loewensrein, U. (1985). Predictable events and excess returns: The case of dividend announcements. Journal of Financial Economics, 14, pp.423-449.

Kale, J. R. and Neo, T. H. (1990). Dividend, uncertainty, and underwriting costs under asymmetric information. Journal of Finance, 39, pp.265-277.

Keim, D. B. (1985). Dividend yields and stock returns: implications of abnormal January returns. Journal of Financial Economics, 14, pp. 473-89.

Keim, D. B. (1986), Dividend yields and the January Effect. Journal of Portfolio Management, 12, pp. 54-60.

Knight, F. H. (1921). Risk, Uncertainty, and Profit. New York: Hart, Schaffner, and Mary.

Lamont, O. (1998). Earnings and expected returns. Journal of Finance, 53(5), pp.1563-87.

Lang, L. and Litzenberger, R. (1989). Dividend announcements: Cash-flow signalling vs free cash flow hypothesis?. Journal of Financial Economics, 24, pp.181-191.

Lanne, M. (2002). Testing the predictability of stock returns. Review of Economics and Statistics, 84, pp.407415.

La Porta, R., Lopez-de-Silanes, F., Shleifer, A. and Vishny. (1997). Legal determinants of external capital. Journal of Finance, 52, pp.1131-1150.

La Porta, R., Lopez-de-Silanes, F., Shleifer, A. and Vishny. (2000). Agency problems and dividend policies around the world. Journal of Finance, 55, pp.1-33.

Lee, C. F., Wu, C. and Djarraya, M. (1987). A further empirical investigation of the dividend adjustment process. Econometrics, 35, pp. 267-285.

Levis, M. (1989). 'Stock market anomalies - A re-assessment based on the UK evidence'. Journal of Banking and Finance, 13, pp. 675-96.

$\mathrm{Li}, \mathrm{O} . \mathrm{Z}$., Liu, H., Ni, C. and Ye, K. (2017). Individual investors' dividend taxes and corporate payout policies. Journal of Financial and Quantitative Analysis, 52 (3), pp. 963-990.

$\mathrm{Li}, \mathrm{W}$. and Lie, E. (2006). Dividend changes and catering incentives. Journal of Financial Economics, 80, pp.293-308.

Lie, E. (2000). Excess funds and agency problems: an empirical study of incremental cash disbursements. Review of Financial Studies, 13(1), pp. 219-248.

Lintner, J. (1956). Distribution of incomes of corporations among dividends retained earnings and taxes. American Economic Review, 46, pp.97-113.

Litzenberger, R. H. and Ramaswamy, K. (1979), The effect of personal taxes and dividends on capital asset prices: theory and empirical evidence. Journal of Financial Economics, 7, pp. 163-95.

Mazur, K. (2007). The determinants of capital structure choice: evidence from Polish companies. International Advances in Economic Research, 13(4), pp.495-514.

McManus, I., Gwilym, O. A. and Thomas, S. (2004). The role of payout ratio in the relationship between stock returns and dividend yield. Journal of Business Finance and Accounting, 31(9-10), pp.1355-1387.

McManus, I., Gwilym, O. A. and Thomas, S. (2006). Payment history, past returns and the performance of UK zero dividend stocks. Managerial Finance, 32(6), pp.518-36.

McMillan, D. G. and Wohar, M. E. (2013). A panel analysis of the stock return-dividend yield relation: Predicting returns and dividend growth. The Manchester School, 81(3), pp. 386-400.

Michaely, R., Thaler, R. H. and Womack, K.L. (1995). Price reactions to dividend initiations and omissions: overreaction or drift?. Journal of Finance, 50, pp.573-608.

Miller, M., and Modigliani, F. (1961). Dividend policy, growth, and the valuation of shares. Journal of Business, 34, pp.411-433. 
Miller, M. and Modigliani, F. (1966). Some estimates of the cost of capital to the electric utility industry. American Economic Review, 56 (3), pp.333-391.

Miller, M. and Scholes, M. (1982). Dividends and taxes: some empirical evidence. Journal of Political Economy, 90(6), pp.1118-41.

Miller, M. and K. Rock. (1985). Dividend policy under asymmetric information. Journal of Finance, 40, pp.1031-52.

Mitton, T. (2004). Corporate governance and dividend policy in emerging markets. Emerging Markets Review, 5, pp.409-426.

Modigliani, F. and Miller, M. (1958). The cost of capital corporation finance and the theory of investment. American Economic Review, 48(3), pp.261-97.

Modigliani, F. and Miller, M. (1961). Dividend policy, growth and the valuation of shares. The Journal of Business, 34(4), pp.411-33.

Modigliani, F. and Miller, M. (1963). Corporate income taxes and the cost of capital: A correction. American Economic Review, 53(3), pp.433-43.

Modigliani, F. and Cohn, R. (1979). Inflation, rational valuation and the market. Financial Analysts Journal, pp.24-44.

Mondher, K., (2011). A re-examination of the MM capital structure irrelevance theorem: A partial payout approach. International Journal of Business and Management, 6(10), pp. 193-204.

Morgan, G. and S.H. Thomas. (1998). Taxes, dividend yields and returns in the UK equity market. Journal of Banking and Finance, 22(40), pp. 405-23.

Mueller, D. C. (1972). A life cycle theory of the firm. Journal of Industrial Economics, 20(3), 199-219.

Myers, S. (1984). The capital structure puzzle. Journal of Finance, 39(3), pp.575-92.

Myers, S. and Majluf, N. (1984). Corporate investment and financing policies when firms have information that investors do not have. Journal of Financial Economics, 13, pp.187-222.

Nielsen, A.E.B. (2006). Corporate governance, leverage, and dividend policy. Working paper, Princeton University.

Nissim, D. and Ziv, A. (2001). Dividend changes and future profitability. The Journal of Finance, 56(6), pp.2111-2133.

O'Connor, T. (2013). Dividend payout, corporate governance, and the enforcement of creditor rights in the emerging markets. Journal of Corporate Governance, 12(1), pp. 7-34.

Ofer, A. R. and Thakor, A. V. (1987). A theory of stock price responses to alternative corporate cash disbursement methods: stock repurchase and dividends. The Journal of Finance, 42(2), pp. 365-394.

Officer, M.S. (2007). Dividend policy, dividend initiations, and governance. Working paper, University of Southern California.

Park, C. (2010). When does the dividend-price ratio predict stock returns?. Journal of Empirical Finance, 17, pp. 81-101.

Penman, S. (1983). The predictive content of earnings forecasts and dividends. Journal of Finance, 38, pp.1181-1199.

Pettit, R. R. (1972). Dividend announcements, security performance, and capital market efficiency. Journal of Finance, 27, pp.993-1007.

Quan, V. D. H. (2002). A rational justification of the pecking order hypothesis to the choice of sources of financing. Management Research News, 25(12), pp.74-90.

Ramalingegowda, S., Wang, C. and Yu, Y. (2013). The role of financial reporting quality in mitigating the constraining effect of dividend policy on investment decisions. The Accounting Review, 88(3), pp.10071039.

Sawicki, J. (2009), Corporate governance and dividend policy in southeast Asia pre-and post-crisis. European Journal of Finance, 15(2), pp. 211-230.

Scholz, J.K. (1992). A direct examination of the dividend clientele hypothesis. Journal of Public Economics, 49, pp. 261-85.

Schumpeter, J. A. (1934). The Theory of Economic Development. Cambridge, MA: Harvard University Press.

Shao, L., Kwok, C. and Guedhami, O. (2009), Dividend policy: balancing interests between shareholders and creditors. Working Paper, Moore School of Business, University of South California.

Shefrin, H. M. and Stateman, M. (1984). Explaining investor preference for cash dividends. Journal of Financial Economics, 13, pp.253-282.

Shefrin, H. M. and Thaler, R. H. (1988). The behaviour life-cycle hypothesis. Economic Inquiry, pp.609-643.

Thaler, R. H. and Shefrin H. M. (1984). Explaining investor preference for a cash dividend. Journal of Financial Economics, 13, pp.253-282.

Thanatawee, Y. (2011). Life-cycle theory and free cash flow hypothesis: evidence from dividend policy in Thailand. International Journal of Financial Research, 2(2), pp.52-60.

Theobald, M. (1979). Capital asset pricing: theory, empirics and implications for portfolio management. Managerial Finance, 5(1), pp. 57-64. 
Hasan, F.

Titman, S. and Wessels, R. (1988). The determinants of capital structure choice. Journal of Finance, 43(1), pp.1-19.

Tsuji, C. (2012). A discussion on the signalling hypothesis of dividend policy. The Open Business Journal, 5 , 1-7.

Valkanov, R. (2003). Long-run regressions: theoretical results and applications. Journal of Financial Economics, 68, pp. 201-232.

Watts, R. (1973). The information content of dividends. Journal of Business, 46, pp.191-211.

Wolf, M. (2000). Stock returns and dividend yields revisited: a new look at an old problem. Journal of Business Economics and Statistics, 18, pp. 18-30.

Yoon, P. S. and Starks, L. T. (1995). Signalling, investment opportunities and dividend announcements. Review of Financial Studies, 8, pp.995-1018.

Yu, X., Wang, Y., Chen, Y. and Wang, G. (2021). Dividend payouts and catering to demands: Evidence from a dividend tax reform. International Review of Financial Analysis. (In Press), 101841. 